\title{
CULTURAL AND LINGUISTIC AFFINITIES AMONGST MEITEI-SIZANG-THADOU
}

\section{Bobita Sarangthem and Lhingneilam Lhouvum}

This paper attempts to highlight the cultural and linguistic affinities amongst Meitei, Sizang and Thadou people. The data are collected from the field works in Imphal (Manipur, India), Tamu (Sagaing division of Myanmar) and Diphu (KarbiAnglong of Assam, India) for Meitei, Sizang, and Thadou respectively. Linguistically, Meitei, Sizang and Thadou share common TibetoBurman feature of SOV word order, agglutinative forms, sharing lexical cognates due to language contact. Culturally, these languages show some similarities; however, Thadou and Sizang are more similar. Nonetheless, languages have been a reflection of those cultural distinctions as well as their identities.

Keywords: Ritual affinities, cognates, birth, marriage.

\section{Introduction}

Linguistically, Meitei, Sizang, and Thadou share similarities in word orders as verb final, clause chaining, and post verbal negation. They are agglutinative languages in which almost all the syllable boundaries correspond to morpheme boundaries. For Example:

Meitei: əycakca-i

1SG rice.eat-ASP

'I eat rice.'

Thadou: kei-n buka-ne-zi-e

$1 \mathrm{SG}-\mathrm{ERG}$ rice1-eat-ASP-DECL

'I (usually) eat rice.'

$\begin{array}{lll}\text { Sizang: } & \text { key onkə-ne } & \text { hi } \\ & \text { 1sGrice 1- eat } \\ & \text { 'I eat rice.' } & \text { DECL }\end{array}$

One of the distinctive features of Sizang and Thadou is verb agreement system consisting of preverbal pronominal elements indexing subject (cf.2\&3). This feature is totally absent in Meitei language. The sound inventories for these 3 languages: Meitei has 24 consonants and 6 vowels and two tones; Sizang has 16 consonants and 15 vowels and three tones; Thadou has 20 consonants, 8 vowels and three tones. However, lexical cognates such as səm 'hair', mei 'fire', nay 'you' etc., are similar in these languages. According to Burling (2003:187), Meitei has often been taken to be a member of the larger NagaKuki groupings, but it would be safest to leave Meitei by itself. On the other hand, Sizang and Thadou belong to the Kuki-Chin group and the Northern-Chin sub-group of languages (Grierson:1904).

The paper further intends to observe the important organizing principles of social relationship and see in what respect they could be considered important in structuring the society. At least three factors could be identified at the basic level. These are marriage, kinship, and ritual. Kinship is the pivot on which rests the whole of society, but its ultimate source is marriage. The importance of marriage and kinship are examined with reference to the Meitei, Sizang, and Thadou. Again, it is ritual which could inculcate a sense of continuity of traditional social relationships. To have a better understanding the following section highlights an ethnographic overview of the three languages.

2. Ethnographic overview of Meitei, Sizang and Thadou

Meitei is the name of the ethnic group and Meiteilon is the language spoken by Meiteis a Tibeto-Burman language spoken chiefly in Manipur state in India, with Myanmar on its eastern border. Located strategically in the Northeastern part of India on the Indo-Myanmar border, the land has been historically the frontier of Southeast Asian and mainland Indian cultures and peoples. Generally identified as Tibeto-Burman on linguistic basis, contemporary Meiteis are a unique people who have absorbed both cultural and racial crosscurrents unto themselves and yet managed to preserve a unique identity of its own. The Meiteis are one of few monarchies in Northeast India from ancient times, the other two

Nepalese Linguistics, vol. 34, 2019, pp. 58-67. 
being Assam and Tripura. The Meiteis have their own script, which was used in writing numerous ancient texts known as Puyas. Meiteilon or Manipuri is the official language of the state, Manipur. It is spoken by approximately 1.2 million people primarily in the Imphal (capital) valley. According to the census 2011 data, the total population of the state is 2570390 . The advent of Hinduism in the early part of the eighteenth century has left its mark in ritual, ceremonial elaboration, and purification. Thus, on the religion based context, Meiteis may be grouped as the Vaisnab Hindus, the Meitei Marup (Sanamahi) cult. Yet, some Meiteis have adopted Christianity and Buddhism in small numbers. This paper doesn't include Christianity and Buddhism but the focus has been given to the Vaisnab Hindus, the Meitei Marup (Sanamahi). Because the ancient rites and rituals are within the roots of belief systems and practices ensuring to follow the path laid down by our ancestors. One of the interesting examples is the obligation to worship Lord Sanamahi, in every Meiteis homestead.

Sizang is a Kuki-Chin language of the TibetoBurman family. Thuavum or Kenedy peak in the Chin state of Burma (Myanmar) is the land of their heritage. According to Grierson (1904: Vol. III. Part III) Siyin belongs to northern Chin subgroups under Kuki-Chin group. Sizang language shares a mutually intelligible language with Vaiphei, Paite or Tedim Chin. Sizang live in Sizang valley or Thuavum which is situated in the present day the Chin State of Burma (Myanmar). Up-to-date official demographic information for Chin State is not available. Referring to the 1931 census of India, Luce (1959) gives the total population of Chin speaker in Burma (Myanmar) is nearly 344,000 with 44 different tribes. In the Chin population, the Sizang are a minority, about ten thousand in number. The present analysis is the Sizang (Siyin) language spoken in Tamu under the Sagaing division of Myanmar (Burma) located at Indo-Myanmar border about $115 \mathrm{Km}$ south-east from Imphal, Manipur (India). According to Grierson (1904), the Siyins are called Tautes or Tauktes in the Manipur records. The meaning of "Taute" is fat folks. Among Paite, Taute" refers only to the Sizang (Vumson,1986). In the history of the sizang people, they fought the
British imperial army who tried to colonize the chin hills at the end of 19th century. They hold that 'a man should spend his life in fighting, hunting, and drinking, whilst labor is intended for women and slaves only'(Grieson, 1904). Actually, Sizang has a close relationship and similarity with the Kuki-Chin group. The cultural attachment is established through contacts and intermarriages. Their culture and tradition are much alike with other sub-ethnic groups of Zo (Chin) people only with a slight variation. The Sizang society is a patriarchal society. Inheritance is legitimate to sons only, and daughters are illegitimate to inherit any inheritance. Like other Chins, Sizang is animistic in their religious beliefs, believing in a variety of good, neutral and evil spirits. The Sizang people believed that "pathian" is the Almighty God who can do only good to them. They believed that there were the evil spirits, "doai" which are against Pathian'swill. Human ailments and death are believed to have been caused by evil spirits who live in mountains caves, rivers, and trees. Sizang is a language with no script.In 1912, Christianity reached the Siyin valley (Khupza Go, 1996). Christianity changed some customs, such as spirit worship, headhunting, and discrimination against women. Today the majority of Sizang people are Christians; the Roman script forms the basis for sizang literature, stories, folktales and religious songs are written in the Roman script to date.

Thadou is a tribal community native to North East India, Chin state and Sagaing Division in Myanmar also known as Burma and in Eastern Bangladesh. The Thadou people are found in the state of Manipur, Assam, Nagaland, and Mizoram in India. The state of Manipur has the majority number of Thadou speakers in India where most of the speakers are either bilingual/multilingual. They have a culture of their own and a distinct language which makes them different from the other mutually intelligible Mizo-Kuki-Chin groups. Thadou belongs to the Kuki-Chin group and the Northern-Chin subgroup of languages (Grierson: 1904). The distribution of the Thadou population in states (2001 census) shows that the majority speakers are from Manipur, Assam, and Meghalaya. 
60 / Cultural and linguistic...

Thadou is a language with no script. Today, the Roman script forms the basis for Kuki literature. The reason may be due to the impact of the Christian missionaries who established a school where the Kuki people lived. Till date, all the literature, books, fictions, stories, folktales and religious songs are written in Roman script. Thadou has been recognized as Scheduled Tribe under Article No. 342 of the Indian Constitution. The present analysis is from the fieldwork conducted in a small locality called "ThadouVeng" in Diphu, KarbiAnglong, Assam.

\section{Social and cultural aspects}

The Meitei, Sizang, and Thadou have a culture of their own, the same way they have distinct languages which make them different and unique from each other. They have their own system of marriage, forms of dancing, a celebration of festivals, conducting of rituals and many other cultural aspects performed in their social life. Still, they have a close relationship and similarities amongst themselves.

Mention may be made of the similarities in the custom of addressing husband or wife's name by the name of their children or younger ones of the family in all the three ethnic groups. It is illustrated as follows:

Meitei:

ma-khoi mamma

'his/her/their mother'

3SG-PL mother

OR

moi-ba

'his/her/their father'

3SG-PLfather

OR

caobi-pa

'father of chaobi'

chaobi father

Sizang:

ə-nu

'his/her mother'

3SG-mother

OR

pum-pa

pum-father

In Thadou:

ə-nu

'his/her mother'
OR

lamcy-pa

lamcy father

In Manipur, women take an active role for the welfare of the society's right from forming Meirapaibilup ' the torch bearer', especially the women organization to protect the youth from consumption of liquor and drugs. Any form of protest or demand is being made against the authority through this organization relating to the issues of a particular place or localities. Yet, out of politeness wife do not address husband by name but a husband can address his wife by name. Of course, to address by their name between spouses is found amongst the educated and younger generations. But, the older generation couple addresses with the third person marker. It is noted that all these three groups are of patriarchal society too.

\subsection{Birth rituals of Meiteis}

A mixed type emerges out of Indigenous Meitei religion and Hinduism practices in Meitei society for their traditional social customs and usages, rites and ceremonies.Nevertheless, the spread of Hindu religion does not destroy the old Meitei religion and culture. It has three birth rituals in the culture for a newborn child such as:

\subsubsection{Ipan-thaba (ipan 'foods and drinks', thaba 'offering')}

This ritual is performed on the sixth day of a childbirth. In the morning a maibi'priestess' perform the ritual at the mangol'veranda' for a long and healthy life of the baby. This shows that most of the pre-Hindu rituals are retained. In continuation of the ritual in the evening, another ritual has been performed known as swasthi puja which is conducted by a priest in the parent's room where an earthen or brass pot with water is place representing the deity. Mantras are chantedby a priest while offering flowers, sesame seeds, fruits etc. to the deity. During this ritual, the child is placed near it on a small monpak 'mattress'. A feast or kher a kind of sweets are also offered to the guest and dakshina in the form of money is also given to show gratitude for their gracious presence.

3SGmother 


\subsection{2 cak-umba (cak 'food', umba 'to introduce')}

$c a k-u m b a$ is usually conducted when the child attains around 5 or 6 months old. If the baby is a boy then cak-umba is taken place when the baby attains six months old. Literally, it is the introduction of solid or normal food to the baby. If the baby is a girl then it is performed at five months old.

\subsection{3 na-hutpa (na 'ear', hutpa 'to pierce')}

Ear piercing or na-hutpa takes place when the child attains three or five years old. In this ceremony, first the head of the child is shaven and then after giving a bath by some virgin girls, the child is dressed up. Later, the child along with parents sits near the sacred fire where the priest conducts the ritual for the well-being of the child. Then a goldsmith pierces the lower lobes of the child's ears and put the golden earrings. In this ceremony, a professional singer sang in the name of god but it is optional. Later on, a sumptuous lunch is entertained to the invitees. It is believed that after na-hutpa ritual the child will be healthier and prevents from any illness. In olden days, ear piercing is performed in a very simpler way such as putting black thread through the pierced earlobes.

\subsection{Birth rituals of Sizang}

Sizang shows a very similar way of conducting birth rituals with Thadous, namely nao-an-thah (nao 'child', an 'food', thah 'distribute'), nao-bilvut or ear piercing, and nao-min-pek or naming of the baby. The naming of the baby is performed after five days for male baby and three days for a female baby. Their names are chosen by the parents. The first male baby is always named after his father's father whereas the female baby is named after her father's mother.

Interestingly, in Sizang as soon as the baby is born a surname is given as a temporary name. It is believed that if the human name is not given then the devil may approach the baby leading to death.

It is noted that all the three communities share common forms of rituals but, it reflects some changes due to the influence of Hinduism and Christianity.

\subsection{Birth rituals of Thadou}

a) naodop-an ( nao 'child', dop 'carry', an 'food'): After a few days of a childbirth, a feast called naodop-an is performed inviting all those who helped in the delivery including the midwife. This ceremony is performed to give gratitude and to thank god for save delivery of a healthy child.

b)naominsah (nao'child', minsah 'naming'): The naming ceremony is called naominsah. It is a customary law in thadou society to coin the name from the last syllable of the grandparent from either of the parents. When a child is named, the last syllable of the person whom it is going to be named after is taken as the first syllable of the child, viz. if the person whom the child is going to be named after is Khupkhomang, then child name has to start with Mang.

c) naopui (nao-child,pui-to bring): literally means blessing ceremony. One is performed in Church and another at the maternal uncle's house. As soon as the child gets his/her name, s/he is then taken to the Church for the blessing ceremony performed by the pastor of the Church and through this ceremony the child earns the membership of the Church and the village. Another ritual involves the blessing ceremony done by the maternal uncle. On this day, the maternal uncle kills pigs, cows etc. and invite close relatives and friends to participate in the ceremony.

d) naobilvu ( nao'child', bil'ear', vu 'pierce'): Ear-piercing of both boys and girls was a common practice. The most common type of earring is the traditional rare beads of red color where the white thread is pushed through the hole. Girls normally pierce their ears. They can wear any types of earrings whether made of gold, silver, metal and any type of their choice as long as they can afford it.

3.4 Meitei marriage or luhongba (lu 'head', hongbo 'to change')

In Meitei society, there are two kinds of Marriage. They are a) Marriage through engagement, b) kanya-katpə. Of all these types, marriage through engagement is believed as one of the prestigious and common forms of a wedding. In earlier days, the kanya-katpo (here the word 'kanya' is a 
62 / Cultural and linguistic...

loanword which means bride/virgin; katpo' to offer') ritual is considered as a marriage meant for a widow or divorcee. Elopement or chenba is also strictly prohibited in those days. If at all, it happens then kanya-katpo is the only option as there will be no marriage ceremony. Thus, in this case, a very simple ritual is held with few people on both sides of the family. In modern days, elopement is quite popular. It is next to the arranged marriage despite strictly prohibited in the earlier period.

There are three main rituals related to the marriage ceremony. They are as follows:

a) haija-pot (haija 'to request', pot 'things') haija-potisalso called as heijing-potmarks the first stage of marriage ceremony which is one of the very important rituals. It is performed one or two days ahead before the Wedding day. Heijapot or engagement is the day when the parents along with friends, invitees, and relatives of the bridegroom visited the bride's place and bring with them different types of fruits, vegetables, betel leaf and betel nut and also sweets. All these things are carried on a well-decorated bamboo basket with cover known as heijingkharai and phingairuk. On this day, the offerings are made to the ancestor and local deities known as lamlai. Meitei's traditional silk attire called phigephanek 'silk sarong', $p h i$ 'clothes' and gold ornaments for the bride are also brought in this ceremony. The bride's father and the bridegroom's father exchanged their greetings than they jointly prayed to the ancestor deity for their children's happy life. After this ritual, all the fruits, sweets especially kabok (parched rice with jaggery) are distributed to one and all present in the ceremony.

b) Bor-barton (bor 'bridegroom', barton 'invitation'): Later in the evening of heijingpot, a boy preferably younger brother of the bride will visit the bridegroom's place for an invitation. For this ritual, a garland of flower especially kundo lei (a kind of jasmine flower) is prepared along with Lei-Chandanand Pana-Kwa (Betel-nuts and betelleaves in a decorated banana leaf) bound nicely by a white cloth. The groom is readyto do the ritual wearing Pheijom and Pumyat ('dhoti' and 'kurta') sitting on a phok 'mat' facing towards the east. Then the younger brother of the bride will hand over Pana-kwa inviting him to come as a bridegroom to the bride's residence on the wedding ceremony.

c) Luhongba or wedding ceremony: The ritualistic preparations are made both at the residence of the groom and the bride on the day of marriage. Generally, in the residence of the bride, the decorated marriage hall or mandopis erected. On this day, lei chandan'sandalwood paste smeared with a flower' is offered to welcome the invitees at the entry point of the mandop. Once the guests are seated,betel-nuts and betel leaves in a decorated piece of round shape banana leaves were presented.

There are some rules for the seat arrangement too like right in the middle of the marriage mandop'marriage hall', luhong phan'the bride and groom's seat' is placed and opposite to this seat,the bridegroom's mother will be seated. The devotional song, especially for the marriage, is sung by isei-sakpa or isei-sakpi ('singer' it can be male or female singers)with the mridanga (kind of drum) drummer. Aband party also follows at appropriate intervals during the ceremony. The main event during the ceremony is the garlanding of the bride and bridegroom with kundopareng 'garland of kundo or a kind of jasmine'. The bride revolves around the bridegroom seven times. The completion of each revolution is marked by showering with flower petals by the bride over the bridegroom. Finally, garlanding takes place after the completion of seven revolutions. Metaphorically, the bride denotes the earth and the groom the sun.

\subsection{Thadou marriage}

Thadou has four kinds of marriages: tsoymu, Sahapsat, zol-tah and kizam-may. In the first two, a proper ceremony is gone through while the latter two amounts to elopement. In the present day, due to the influence of Christianity, Marriages are now solemnized in the church by ordained pastors in accordance with the church. Monogamy, cross cousin marriage, marriage by elopement, marriage by negotiation, the bride price is some important aspects of the marriage system. There is no restriction to inter and intra marriages with other tribes or outside the village. And also the 
remarriage of the widow and widower is permitted.

\subsection{Sizang marriage}

Sizang has a custom that forbids marriage between a man and a woman from the same village, and, it is known as phungkhawm marriage. Normally, eligible candidates are from different villages. The eldest man of the bridegroom clan known as mopozang or advance man went to the bride's place for the proposal.

modokzu or a 'pot of liquor' is presented to the bride's family indicating that he came along with a marriage proposal. If they didn't agree with the marriage affair, then they would return back the modukzu. If they are willing for the marriage ceremony to be held, then it's a green signal or positive reply. Accordingly, mopozang will visit the bride's place to fix the date of the wedding.

On the day of mopui-ni or the day of bride's leaving her parental place, her parents entertain their friends and relatives with tamsi or the biggest animal brought from bridegroom's side. At evening the bride leaves for bridegroom's place along with friends and the elders. On arrival at the main gate of the bridegroom's house, the eldest person(male) would call loudly like -"we are coming back with son, daughter, maize, and millets". The call was replied by an older man as" we welcome you all. Come back with son, daughter, maize, millets, and mithun." After this, the older man would spill the liquor from his mouth to the outward side of the main gate. After the completion of this ritual, the bride can enter the new house.

\subsection{Thadou's death rituals}

Death ritual among Thadou can broadly be divided into two: thi-pha (natural death) and thi-se (unnatural death).

thi-pha (thi 'death', pha 'good'): Natural death includes death caused by sickness and old age. During the pre-Christian day, there have been certain perceptions regarding the cause of diseases and death. The most popular belief was that death is associated to be work of evil spirit which is believed to have dwelled everywhere. Burial for this type of death varies from person to person depending on the social position he held during his lifetime. On the day of burial, a funeral rite called kosa is performed by killing a pig or mithun to entertain the people who have participated in the funeral. The head of animals killed is then used to adorn deceased grave along with other numbers of wild animals he had killed in his time. In all case of natural death, corpses were buried in burial ground within the village.

thi-se (thi 'death',se 'bad'): In earlier days unnatural death like drowning, murdered, suicide,etc. is not given a proper funeral rite. They believe that such a person never reaches mi-thixo( $m i$ 'man', thi 'death', xo 'village') and they are buried without any ceremony because their soul is already condemned. Such dead bodies are buried outside the village to avoid further misfortune. After corpse of an unnatural death is buried, 'inthe'(in 'house', the? 'to sweep'), a rite for purification of the house is performed by $x o$ thempu( хо 'village', thempu 'priest').

However, with Christianity, such belief and practice are changed to a certain extent. Thadou follows and adheres to the common burial ground and equal ceremony for all types of death. Today, if a person dies in the morning, $\mathrm{s} /$ he gets buried on the same day itself, whereas, if anybody dies in the evening, the person is buried next day as per Christian service. Kosa (funeral feast) is still in practice and is performed after two or three days of the death of a person.

\subsection{Sizang's death rituals}

Sizang has three different death rituals. Sizang's death ritual is conducted under the Thaamvel (thaam 'tent', vel 'covered with mat'). The dead person was placed in the thaam, the villagers drink and dance; this ritual is known as Mithi mai. After mithimai, the dead body was placed in a coffin and kept inside the house again; this ritual is known as the mithipanglai dead body at the center of the house). A small portion of food is placed on the coffin as mithipanglai was considered as still alive ones. The dead body could be kept as long as the family desired, and when they were readied, they began to perform the final funeral, then only the dead body be taken to the cemetery. Mi-thi-vui (mi 'men' thi 
64 / Cultural and linguistic...

'dead',vui- 'go') is the ritual on the final funeral where the dead body was taken to the cemetery for burial, followed by young unmarried males and females dance holding hand in hand and singing a farewell song.

\subsection{Meitei's death rituals}

In Meitei culture the dead body is cremated. The dying person is taken out of the house to the verandah. The body is bathed and dressed in white clothes before it is cremated. The cremation is done on the bank of a river or lake. Nowadays, cremation is conducted at crematoria. The body is placed on the pyre, the next of the kin walks around the pyre with a fire burning from the sticks he is holding. The priest does incantations and then the pyre is lit. The males stay back until the body is consumed by fire. The people who attend the funeral do not go home directly. They are allowed to go after taking bath. They can enter the house only after they are received by a person with any sort of fire. They believe the evil spirits are then removed. The deceased person's bedding is burnt. For Meitei hindus, the temple bones or the asthi of the deceased are collected from the ashes and within a year taken to holy places. On the fifth day after the cremation astisancoi (for Meitei hindus) or mayanileihun is performed. Later, on the twelfth/thirteenth day lannathouram or sorat (The word derives from shraddha) is conducted and finally, on the completion of one year, the completion of death ritual known as phiroi is conducted with a grand feast to the invitees to show gratitude.

\section{Kinship terminology}

The study of the kinship term is highly dependent on knowing the social structure of the community. It also shows the importance of kinship terms to make a clear distinction between terms of address and terms of reference which act like a mirror reflecting the socio-ethnic network.

\subsection{Meitei}

In Meitei society, kinship may be classified based on the affinal or relationship made and consanguineal or blood relationships. The terms of address differ from the terms of reference. Terms of address:

pabung (polite form) 'father'

$$
\begin{aligned}
& \text { i-ma/mama 'mother' } \\
& \text { i-yamba/tadə/ibung 'elder brother' } \\
& \text { i-ce/cece 'elder sister' } \\
& \text { i-nao(younger)nupi 'younger sister' } \\
& \text { i-nao(younger)nupa 'younger brother' } \\
& \text { i-ton/k } \mathrm{k}^{\mathrm{h}} \text { ra/mamma 'uncle' } \\
& \text { i-təi 'brother-in-law' (female ego) } \\
& \text { i-bai 'brother-in-law'(male ego) } \\
& \text { i-nəmmə 'sister-in-law'(female ego) }
\end{aligned}
$$

It is noted that Meitei terms of reference have to prefix either $i$-, nəor $m o$ - are the first person, second person, and third person possessive prefixes. They are prefixed to kinship terms.

\begin{tabular}{|c|c|c|}
\hline $\begin{array}{l}\text { Terms used } \\
\text { by RKs }\end{array}$ & Gloss & $\begin{array}{l}\text { Terms used } \\
\text { by the } \\
\text { Commoners }\end{array}$ \\
\hline a-si & 'mother' & ima \\
\hline em-si/ine-si & 'paternal aunt' & ine/inem \\
\hline don-si & 'maternal aunt' & indon \\
\hline em-si & 'elder sister' & ice \\
\hline m-si & 'maternal uncle' & mamə \\
\hline & 'elder brother' & ibuy \\
\hline
\end{tabular}

For instance:

$\begin{array}{ll}\text { i-pa } & \text { 'my father' } \\ \text { i-ma } & \text { 'my mother' } \\ \text { nə-pa } & \text { 'your father' } \\ \text { nə-ce } & \text { 'your sister' } \\ \text { mə-bok } & \text { 'his/her grandmother' } \\ \text { mə-pa } & \text { 'his/her grandmother' } \\ \text { mə-ma } & \text { 'his/her mother' }\end{array}$

The kinship terminology in Meitei shows differentiation between commoners and the royal descendants known as RK's or Rajkumar's and Rajkumari's where the suffix-si is added to the kinship terms as polite marker.

For example:

Further, Pramodini (1989) mentions "The royal group is no longer in control of the use of language, instead, the socio-economic conditions and social status of the people play a greater role in determining the use of the different variables of kinship terms. Some of the terms once used only amongst royal descendants are being taken over in modern society by some of the commoners".

The usage of the second personal pronoun should be taken care of while using as a term of reference 
especially to older people as it considers being derogatory. For instance;

nəy-gi/ (som-gi) pabuy-gi minkarino

2SG-GEN / 2SG (POL) father-GEN name QN

'What is your father's name?' is the correct form to ask a question to older/stranger/person of higher status people. But it is an unacceptable form to utter such as;

nəy-ginə-pa-giminkarino

2SG-GEN 2POSS-father-GEN nameQN

'What is your father's name?'

This form of conversation is considered to be impolite or derogatory. However, it is acceptable if you ask a child otherwise it is impolite.

\subsection{Sizang}

Treatment of kinship terms in Sizang is an interesting area of study. The term of address varied in accordance with the numbers of generation. Grandfather's generation is ' $p u$ ', father's generation is ' $p a$ ' etc. Any male who is in the same generation with his father, he is called ' $p a$ ' and if in female case she is called ' $n i$ ' (i.e. aunty). If a male person belongs to grandfather's generation, he is called ' $p u$ ' and for the female person, she is called ' $p i$ '. Thus, the forms of address are conditioned by kinship relation or age or the ego-male or female.

4.2.1 Kinship terms of address:Various kinship terms of address are illustrated as follows:

Direct generation relation:

$\begin{array}{ll}\text { pá } & \text { 'father' } \\ \text { ná } & \text { 'mother' } \\ \text { u-pasəl } & \text { 'elder brother' } \\ \text { u-numey } & \text { 'elder sister' } \\ \text { nəw-nu } & \text { 'younger sister' } \\ \text { nəw-pa } & \text { 'younger brother' }\end{array}$

Paternal relations:

$\begin{array}{ll}\text { pu } & \text { 'father's father' } \\ \text { pi } & \text { 'father's mother' } \\ \text { pa-pi } & \text { 'father's elder brother' } \\ \text { pa-lay } & \text { 'father's middle brother' } \\ \text { pa-nəw } & \text { 'father's younger brother' } \\ \text { ni-pi } & \text { 'father's elder sister' } \\ \text { ni-lay } & \text { 'father's middle sister' } \\ \text { ni-nəw } & \text { 'father's younger sister' }\end{array}$

Maternal relations:

$\begin{array}{ll}\text { pu } & \text { 'mother's father' } \\ \text { pi } & \text { 'mother's mother' } \\ \text { pu-pi } & \text { 'mother's elder brother' } \\ \text { pu-lay } & \text { 'mother's middle brother' } \\ \text { pu-nəw } & \text { 'mother's younger brother' } \\ \text { ni-lay } & \text { 'father's middle sister' } \\ \text { nu-neàw 'mother's sister' } \\ \text { nu-neàw-puy 'mother's elder sister' } \\ \text { nu-neàw-nəw 'mother's younger sister' }\end{array}$

In-law relations:

$\begin{array}{ll}\text { teak-nu } & \text { 'mother-in-law (female ego)' } \\ \text { teak-pa } & \text { 'father-in-law (female ego)' } \\ \text { suy-nu } & \text { 'mother-in-law'(male ego) } \\ \text { suy-pa } & \text { 'father-in-law (male ego)' } \\ \text { suapuy-u } & \text { 'husband's elder brother' } \\ \text { suapuy-nəw'husband's younger brother' }\end{array}$

4.2.2 Address by name: Age of the addressee is the deciding factor in thechoice of appropriate kinship term. For senior ones, the prefixation of $u$ to proper name or the kinship terms indicates seniority, except in suapuy- $u$ 'husband's elder brother'. Forjunior ones like son, daughter, younger brother, younger sister etc. Generally, names are used as address terms. For those people of similarage group is addressed by their names. Addressed by their name between spouse is found amongst the educated and younger generations. But, the older generation couple addresses with the third person marker $ə$-. Thus, әра 'his father' is used by the wife for addressing her husband, while әпи 'his mother' for addressing his wife. Younger relations like'nephew', 'niece', 'son', 'daughter', etc. are generally addressed by theirrespective names.

Terms of reference: One of the important characteristics of Sizang language is the use of personal pronoun prefixes with kinship terms usedasterms of references. In other words, Sizang uses a system of affixationfor expressing various kinship relationships. The kinship terms require thepronominal prefixes, namely $k \partial$ - for the first person, na- for the second person anda- for the third person. In short, these pronominal prefixes function as a possessive marker and it makes complete sense with the kinship terms of reference.

This is illustrated in the following examples: 
66 / Cultural and linguistic...

\begin{tabular}{|c|c|}
\hline $\begin{array}{l}\text { Terms of address } \\
\text { pá 'father' }\end{array}$ & $\begin{array}{l}\text { Reference terms } \\
\text { kə-pa 'my father' } \\
\text { nə-pa 'your father' } \\
\text { ə-pa 'his/her father' }\end{array}$ \\
\hline nú 'mother' & $\begin{array}{l}\text { kə-nu 'my mother' } \\
\text { nə-nu 'your mother' } \\
\text { ə-nu'his/her mother' }\end{array}$ \\
\hline tapa 'son' & $\begin{array}{l}\text { kə-tapa 'my son' } \\
\text { nə-tapa 'your son' } \\
\text { ə-tapa 'his/her son' }\end{array}$ \\
\hline tanu 'daughter' & $\begin{array}{l}\text { kə-tanu 'my daughter' } \\
\text { nə-tanu'your daughter' }\end{array}$ \\
\hline
\end{tabular}

\subsection{Thadou}

Kinship relationship among the thadou can be broadly divided based on the consanguine and affinal relationship i.e. relationship between the parent and children, the relationship between husband and wife. The degree of kinship bond plays a vital function in the Thadou society. The kinship terms have a specific role to play in a person's life as well as on auspicious gatherings where the entire kin and clan members are present. Some of the kinship terminologies are as follows:

Terms of address:

\begin{tabular}{|c|c|}
\hline he-pu & $\begin{array}{l}\text { 'father's father/mother's } \\
\text { father/mother's brother/mother's } \\
\text { brother's son' }\end{array}$ \\
\hline he-pi & $\begin{array}{l}\text { 'father's mother/mother's mother/ } \\
\text { mother'sbrother'wife' }\end{array}$ \\
\hline he-pa & $\begin{array}{l}\text { 'father/husband's father/wife's } \\
\text { father }\end{array}$ \\
\hline he-nu & $\begin{array}{l}\text { 'mother/husband's mother/wife' } \\
\text { mother }\end{array}$ \\
\hline he-pa-len & 'father's elder brother' \\
\hline he-nu-len & 'father's elder brother's wife' \\
\hline he-gay & 'father's sister's husband' \\
\hline he-ni & 'father's sister' \\
\hline he-u & 'elder brother; elder sister' \\
\hline tu-te & 'grandchildren' \\
\hline tu-pa & 'grandson' \\
\hline tunu & 'granddaughter' \\
\hline tsate & 'children' \\
\hline tsapa & 'son' \\
\hline tsanu & 'daughter' \\
\hline zitsa & 'husband-wife' \\
\hline zipa & 'husband' \\
\hline
\end{tabular}

$\begin{array}{ll}\text { zinu } & \text { 'wife' } \\ \text { nao/boi 'younger brother or younger } \\ \text { sister' }\end{array}$

Terms of Reference:

Thadou language has a similar pattern with Sizang language, especially, the use of possessive pronominal prefixed with kinship terms functioningas terms of references. For example,

$\begin{array}{ll}\text { kə-pa } & \text { 'my father' } \\ \text { nə-pa } & \text { 'your father' } \\ \text { əma-pa } & \text { 'his/her father } \\ \text { kə-tsapa } & \text { 'my son } \\ \text { nə-tsapa } & \text { 'your son' } \\ \text { əma-tapa } & \text { 'his/her son' }\end{array}$

It is noted that in Thadou, a person regards all the clansmen who are his grandfather's age as hepi, his father's age as hepa, his mother's age as henu, his elder person as $h e-u$, his younger brothers and sisters as nao or boi. The morpheme heindicates the polite terms in this very language. These terms are used in addressing others irrespective of which clan one belongs to their age.

\section{Conclusion}

From the above discussion, it has been noted that there are some similarities amongst the languages sharing common Tibeto-Burman features such as OV word order, the kinship terms are prefixed with secondary singular form ofpersonal pronounindicating the inalienable to the possessor and also as terms of reference. However, certain dissimilarities is observed in Meitei from that of Sizang and Thadou, especially with the verb agreement system, which is absent in Meitei language. Sizang, and Thadou shows light differences when compared with Meitei marriage and death rituals.In the present situation, nobody can expect the ethnic groups to continue their own independent ways based solely on traditional values and customary. Due to globalization, people tend to change their lifestyles that may be accelerated or slow type to respond to the totality of structure and function of the particular society and its culture. However, it cannot go beyond comparative tone as they tried hard to preserve their culture at the most. Thus, the Meitei, Sizang, and Thadou have a culture of their own, the same way they have distinct languages which make 
them different and unique from each other.The various differences amongst these ethnic groups meted out of religion are also highlighted in this paper. The present paper will be helpful in further research from the perspective of Ethnolinguistics in the near future.

$\begin{array}{ll}\text { Abbreviations } \\ \text { 1SG } & \text { First person pronominal } \\ \text { 2SG } & \text { Second person pronominal } \\ \text { 2POSS } & \text { Second person possesssive } \\ \text { 3SG } & \text { Third person pronominal } \\ \text { ASP } & \text { Aspect } \\ \text { DECL } & \text { Declarative } \\ \text { GEN } & \text { Genetive } \\ \text { PL } & \text { plural } \\ \text { POL } & \text { Polite } \\ \text { QN } & \text { Wh-question }\end{array}$

References

Burling, Robbins. 2003. The Tibeto-Burman languages of Northeast India. In Graham Thurgood \& Randy J. Lapolla (eds.), SinoTibetan languages, 169-191. London / New York: Routledge.

Grierson, G.A. 1904. Linguistic survey of India. Vol.III, Tibeto-Burman family, part III, Reprinted 1967. Delhi: Motilal Banarsidass.

Holmes, Janet. 2008. An Introduction to sociolinguistics. U.K : Pearson Education Limited

Pramodini, N. 1989. Kinship Terminology in Meiteilon: a Sociolinguistic study. Linguistics of the Tibeto-Burman Area 12:2, 123-136.

Sarangthem, Bobita. 2010. Sizang (Siyin) Grammar, Unpublished thesis. Manipur University.

Sarangthem, Bobita. 2017. Towards the understanding of surnames and naming patterns in Meitei society. Journal of humanities and social science 22:11, 35-43.

Shaw, W., 1929. The Thadou Kukis. New Delhi: Cultural Publishing House.

Trudgill, Peter, 1995. Sociolinguistics: an introduction to Language and Society. UK: Penguin. 